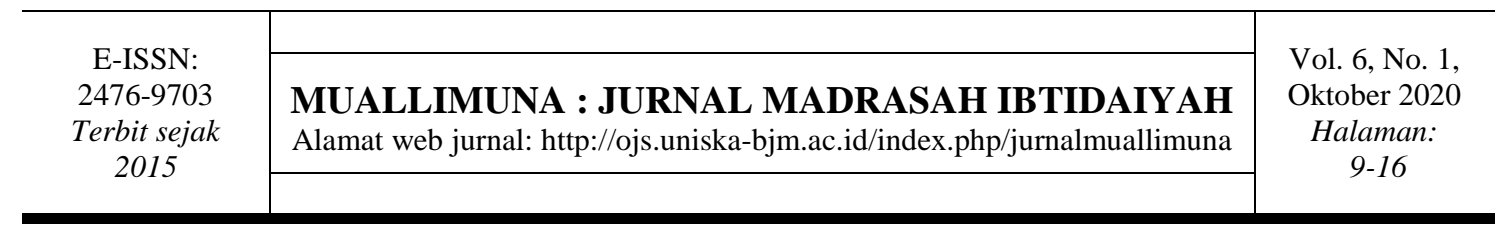

\title{
METODE VAKT SOLUSI UNTUK KESULITAN BELAJAR MEMBACA PERMULAAN PADA ANAK HIPERAKTIF
}

\author{
Eri Susanto ${ }^{1}$, Aninditya Sri Nugraheni ${ }^{2}$ \\ 1,2 Program Pascasarjana UIN Sunan Kalijaga Yogyakarta \\ 1 eriisusanto21@gmail.com, ${ }^{2}$ anin.suka@gmail.com
}

\begin{abstract}
Abstrak: Riset ini dilakukun dengan tujuan untuk memecahkan masalah yang dihadapi oleh guru kelas ketika mengajarkan membaca anak ABK dengan tipe hiperaktif. Metode VAKT yang focus dengan penggunaan seluruh multisensori yang dimiliki manusia, diharapkan dapat memberikan solusi guru dalam mengajar siswa ABK tipe hiperaktif dengan kesulitan belajar membaca permulaan. Penelitian ini merupakan hasil dari kajian pustaka dengan cara riset kepustakaan. Hasil penelitian ini mengungkapkan langkah-langkah pembelajaran dengan metode VAKT ini yaitu; langkah pertama dari aspek visual yaitu, guru mulai membagikan katu huruf lalu mengucapkannya, lalu siswa diminta untuk melihat dan ikut mengucapkannya, langkah kedua dari aspek auditori, guru mengucapkan bunyi guru dan siswa mendengar dan mengikutinya, selanjutnya guru akan bertanya ke siswa bunyi huruf tersebut lalu siswa menyebutkan bunyinya, langkah ketiga dari aspek kinestetik, guru menuliskan huruf yang diajarkan diudara, dan siswa mengikutinya. Dan langkah yang terakhir adalah aspek taktil, guru membagikan kartu huruf lagi dan setelah terbagi rata kesemua siswa, guru meminta siswa untuk meraba kartu huruf dengan mengikuti bentuk huruf yang ada di kartu.
\end{abstract}

Kata Kunci: metode VAKT, membaca permulaan, anak hiperaktif

\section{VAKT METHOD SOLUTION TO DIFFICULTY LEARNING TO BEGIN READING IN HYPERACTIVE CHILDREN}

Abstract: This research addressed problems faced by classroom teachers when teaching reading for children with special needs with hyperactive types. The VAKT method, which focuses on the use of all the multisensory possessions of humans, is expected to provide a solution for teachers in teaching hyperactive type ABK students with difficulty learning to read initially. This research is the result of the literature review through library research. The results of this study reveal the learning steps using the VAKT method, namely; The first step is from the visual aspect; namely, the teacher begins to distribute the letters then pronounce them, then students are asked to see and participate in saying them, the second step is from the auditory aspect, the teacher says the sound of the teacher and the students hear and follow it. The teacher will ask the students the sound of the letters, and then students mention the sound; the third step is from the kinesthetic aspect, the teacher writes the messages taught in the air, and the students follow it. And the last step is the tactile aspect, the teacher distributes the letter cards again, and after it is evenly divided all the students, the teacher asks students to feel the letter cards by following the letter shapes on the cards.

Keyword: VAKT method, beginning reading, hyperactive child 


\section{PENDAHULUAN}

Pendidikan adalah hak yang mendasar bagi masing-masing individu warga negara di Indonesia. Pendidikan itu bukan hanya kegiatan pemindahan ilmu pengetahuan dari guru ke siswa saja. Tetapi sebagai proses perubahan perilaku dari yang individual ke perilaku yang lebih peduli dan mengarah ke sikap kedewasaan. Selain itu dalam pendidikan nasional di Indonesia bertujuan selain proses perubahan perilaku menuju kedewasaan tetapi juga harus berlandaskan ketakwaan kepada Tuhan YME dan berakhlak mulia.(Raudlatul Jannah 2016) Pendidikan sangat penting untuk semua orang, tak terkecuali bagi anak dengan kebutuhan khusus (ABK). Hak memperoleh pendidikan bagi anak berkebutuhan khusus dijamin di UU Sisdiknas no 20 tahun 2003 pasal 5 ayat 2.

Sering kita ketahui bahwa anak ABK bersekolah di SLB dan tidak bisa berbaur dengan siswa di SD umum. Seiring dengan dikeluarkannya Permendiknas no 70 tahun 2009 tentang sekolah penyelenggara pendidikan inklusi, peluang anak ABK untuk bersekolah di SD umum terbuka lebar. Menurut Batubara, pendidikan dasar di SD/MI merupakan tahap awal dalam menanamkan konsep untuk menghadapi jenjang berikutnya.(Batubara 2018) Hak memperoleh pendidikan dasar merupakan hak setiap anak tak terkecuali pada anak ABK. Tentu ini kebijakan ini menemui hambatan utamanya dari tenaga pendidik yang belum terbiasa menangani siswa ABK.

Tenaga pendidik yang belum terbiasa menangani siswa ABK tentu akan kesulitan dalam mengajarnya. Hal ini dibuktikan dari studi pendahuluan yang dilakukan penulis kepada ibu Sumarsih S.Pd guru kelas 3 di MI Al-Iman Tambakrejo. Beliau kesulitan dalam mengajar anak ABK bertipe hiperaktif dikarenakan anaknya sering usil mengganggu temannya sehingga pembelajaran terganggu. Anak ABK yang bertipe hiperaktif ini ketika pembelajaran Bahasa Indonesia juga tidak mau membaca jika diberi tugas oleh guru dan lebih memilih mengganggu temannya. Padahal materi membaca yang termasuk ke dalam materi dasar dalam pembelajaran Bahasa Indonesia begitu penting dalam keseharian. Bahasa itu sendiri menurut Khaliq merupakan sarana utama untuk bisa melakukan komunikasi dan interaksi dengan orang lain. (Khaliq, Barsihanor, dan Arifa 2020) Selain itu Bahasa juga berfungsi sebagai alat mengapresiasi perasaan dan pikiran orang lain.(Arifa 2018) Jadi Ketika anak memiliki kesulitan dalam pembelajaran Bahasa Indonesia terutama pada anak ABK bertipe hiperaktif maka harus segera dicarikan jalan keluarnya, jika tidak maka anak akan kesulitan dalam berinteraksi dan memahami orang lain.

Menurut Putra, anak ABK bertipe hiperaktif ini mengalami kesulitan dalam hal meningkatkan kretivitas melalui literasi.(Putra 2018) Penelitian lain juga menjelaskan bahwa anak hiperaktif ketika menerima pembelajaran oleh guru, anak akan tidak memperhatikan dan konsentrasinya gampang teralihkan sehingga materi tidak akan sampai ke anak ABK tipe hiperaktif ini.(Tentama 2009) Sehingga ketika tidak ditemukan cara atau metode pembelajaran yang tepat dan mampu mengakomodir anak ABK tipe hiperaktif ini, maka pembelajaran tidak akan efektif dan pasti terganggu.

Banyak metode pembelajaran yang dapat diimplementasikan oleh pendidik yang mampu mengakomodir anak ABK tipe hiperaktif ini terkhusus dalam materi membaca permulaan. Salah satu metode yang peneliti anggap kompatibel untuk anak ABK tipe hiperaktif yang kesulitan dalam membaca permulaan adalah metode VAKT. Metode VAKT ini mampu mengimplikasikan seluruh indra yang ada dalam diri manusia antara lain; visual/penglihatan, auditori/pendengaran, kinestetik dan taktil.(Puput dan Tjutju t.t.) 
Metode VAKT merupakan metode pembelajaran yang pertama kali dicetuskan oleh Grace M.Fernald. Metode ini lebih memfokuskan pada pelibatan semua indera yaitu visual/penglihatan, auditori/pendengaran,kinestetik/gerak dan taktil/perabaan. Metode ini akan memberikan gambaran pengalaman belajar yang optimal karena melibatkan semua indera sehingga akan efektif jika diterapkan untuk anak hiperaktif dengan kesulitan belajar dalam membaca permulaan.(Destiani 2016)

Riset ini dilakukan sebagai problem solving yang dihadapi pendidik di kelas ketika menghadapi anak ABK tipe hiperaktif. Dengan menawarkan metode VAKT yang focus dengan penggunaan seluruh multisensori yang dimiliki manusia, diharapkan dapat memberikan solusi guru dalam mengajar siswa ABK tipe hiperaktif dengan kesulitan belajar membaca permulaan.

\section{METODE}

Riset ini menggunakan pendekatan kualitatif deskriptif dan metodologi penelitiannya adalah studi kepustakaan. Peneliti melakukan studi kepustakaan dengan cara riset kepustakaan baik di perpustakaan maupun dalam jurnal-jurnal ilmiah yang terakreditasi yang diperoleh dari jurnal-jurnal yang terdapat pada website Sinta Jurnal maupun Google Scholar, selain itu juga melakukan pengamatan lapangan ke Sekolah Dasar sebagai data penunjang/sekunder. Hasil dari studi kepustakaan berupa data-data literatur diantaranya; artikel jurnal ilmiah yang kemudian sebagai sumber primer dan hasil pengamatan lapangan ke Sekolah dijadikan data penunjang/ sekunder. Dari kedua jenis data kemudian dibandingkan setelah itu ditarik kesimpulan.

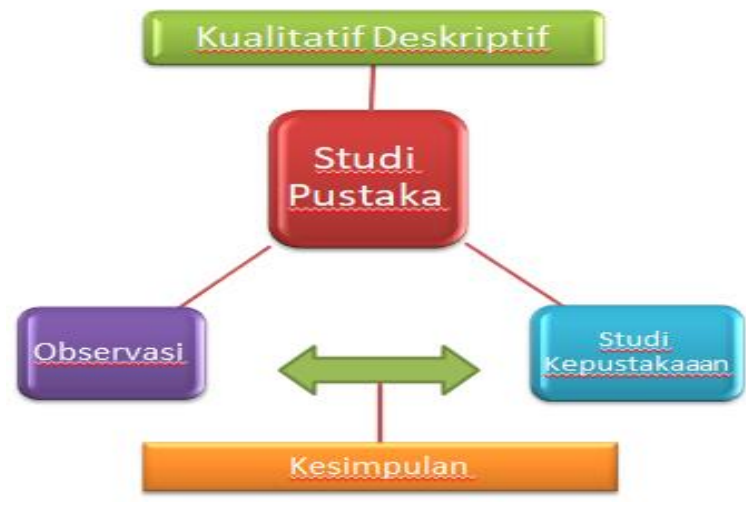

Bagan 1. Metodologi penelitian

\section{HASIL DAN PEMBAHASAN \\ Hasil}

Anak dengan ADHD (Attention Deficit Hyperactivity Disorder) atau yang familiar sering disebut dengan anak hiperaktif merupakan tipe gangguan psikologi yang memiliki gejala dengan ketidak mampuan anak untuk memfokuskan perhatiannya pada suatu objek/keadaan yang dihadapi. Anak yang hiperaktif biasanya memiliki kemampuan dibawah rata-rata dalam pemusatan perhatian dibandingkan anak seusianya. Selain itu juga ditandai dengan perilaku hiperaktif dan impulsive yang berlebihan.(Roshinah, Nursaliha, dan Amri 2014)

Menurut Green dan Rabiner, terdapat 25\% siswa usia sekolah yang di diagnosis mengalami ADHD/hiperaktif. Sedangkan menurut Zachor,Hodgens dan Patterson menyebutkan bahwa, kurang lebih 8-12\% anak-anak usia sekolah (dengan indeks 9,2 
pada laki-laki dan 3,0 pada anak perempuan) memenuhi kriteria mengalami gangguan ADHD/hiperaktif.(Putri Pangesti Rahayu 2016)

Anak hiperaktif tentu dan sangat mungkin akan mengalami keterlambatan maupun keterbelakangan dalam perkembangan. Saat anak seusianya sudah mulai dapat berbicara, anak hiperaktif seringkali belum bisa. Demikian juga dalam hal kemampuan akademis tentang cara memusatkan perhatian juga kesulitan. Sehingga dapat menyebabkan kesulitan ketika disekolah.(Akbar 2017) Sehingga penting untuk seorang pendidik memiliki cara yang tepat dalam menangani anak hiperaktif ini supaya tidak kesulitan dalam belajar utamanya dalam membaca, karena membaca/literasi ini merupakan salah satu fondasi awal seseorang untuk dapat belajar .

Dari hasil obervasi di MI Al-Iman Tambakrejo, diketahui bahwa anak hiperaktif memiliki kesulitan di materi membaca. Anak dengan hiperaktif seringkali tidak mau mengikuti pelajaran materi membaca dan menganggapnya membosankan. Dikhawatirkan anak hiperaktif akan memiliki kemampuan akademis dalam hal ini membaca yang tidak sama dengan teman sebayanya, dan berimabas dengan hasil belajarnya. Berikut foto anak hiperaktif saat pembelajaran di kelas;

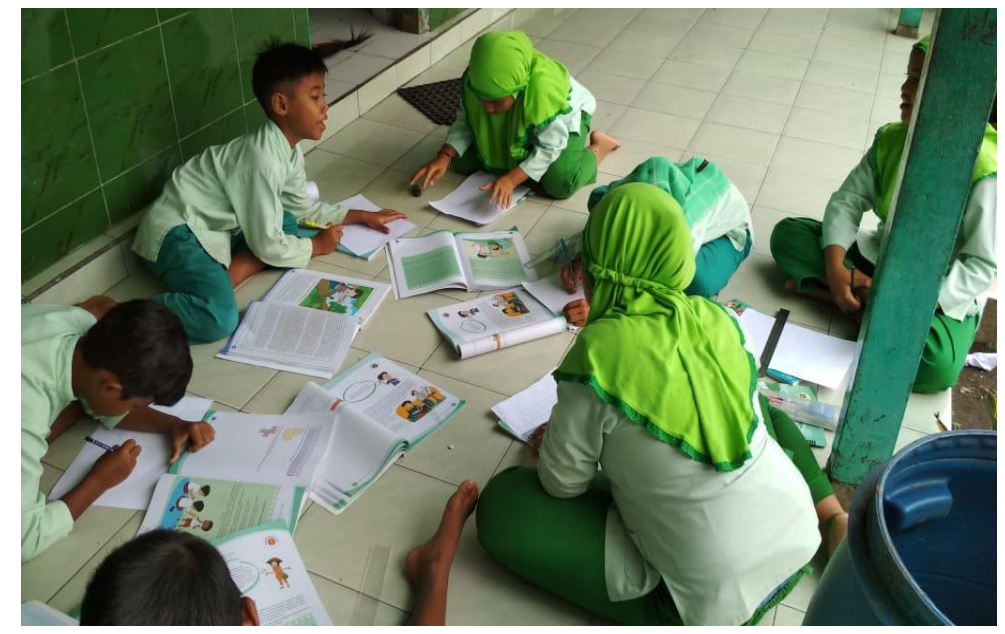

Gambar 1. Kegiatan membaca di luar kelas

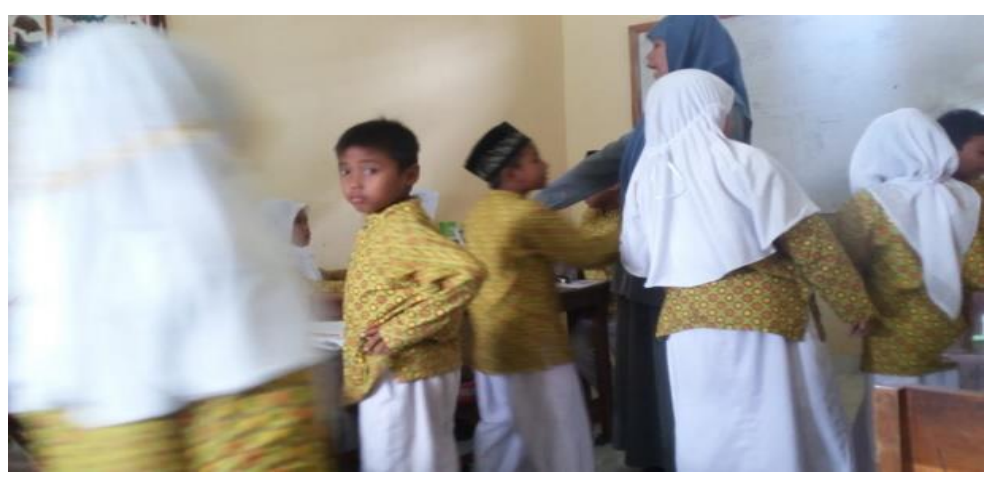

Gambar 2. Foto anak hiperaktif ketika pembelajaran di MI Al-Iman

Anak ABK hiperaktif ini mengalami kesulitan dalam hal meningkatkan kretivitas melalui literasi/membaca. Kemampuan literasi yang tinggi dibutuhkan oleh setiap anak untuk dapat menyelesaikan masalah, tak terkecuali untuk anak hiperaktif. (Putra 2018)

Kemampuan literasi yang tinggi tentunya tidak instan tertanam pada setiap anak. Tentu dibutuhkan budaya membaca di sekolah maupun di rumah. Anak hiperaktif 
memiliki kekurangan dalam focus atau berkonsentrasi, ketika guru memberikan pembelajaran tentang membaca, anak hiperaktif merasa bosan mengalihkan perhatian ke hal lain. Inilah yang membuat tingkat literasi anak hiperaktif rendah.

Menumbuhkan tingkat literasi harus harus dimulai dari yang sederhana contohnya pada materi membaca permulaan. Membaca permualaan merupakan dasar bagi anak untuk dapat menguasai bidang studi. Jika anak tidak mempunyai kemampuan tersebut akibatnya, dirinya akan banyak mengalami kesulitan dalam memahami pelajaran di kelas selanjutnya.(Puput dan Tjutju t.t.) Untuk mengatasi kemampuan literasi/membaca permulaan pada anak hiperaktif solusinya dengan menerapkan metode multisensori atau sering kita sebut metode VAKT.

Metode VAKT merupakan metode yang memfokuskan pada pelibatan semua sensori manusia atau biasa disebut pendekatan/metode multisensori. Metode VAKT diasumsikan anak dapat belajar dengan optimal dan menguasai materi dengan baik. Jika, materi yang diajarkan disajikan dengan melibatkkan semua sensori/berbagi modalitas yaitu visual, auditori, kinestetik dan taktil.(Sutisna dan Rahmawati 2018)

Terdapat beberapa penelitian sebelumnya yang menguji tentang metode multisensory/metode VAKT dalam membaca permulaan yaitu penelitian yang dilakukan oleh (Nirlianti t.t.) berdasar hasil siklus yang dilakukan rata-rata kelas menjadi 80,28 dan tingkat keberhasilan dalam belajar sebesar $88 \%$. Oleh karena itu, penerapan VAKT dapat meningkatkan kemampuan membaca permulaan siswa.

Penelitian lain yaitu dilakukan oleh (Faradila t.t.) menyebutkan bahwa metode VAKT efektif dan dapat diimplementasikan dalam peningkatan kapabilitas membaca permulaan pada anak tunagrahita ringan. Selain itu (Nurraga 2016) menyebutkan bahwa pada ketiga baseline terdapat peningkatan rata-rata pada level subjek, dengan demikian metode VAKT mampu menambah kapabilitas membaca permulaan pada anak tunagrahita ringan.

Dari beberapa penelitian terdahulu diketahui bahwa metode VAKT dapat meningkatkan kompetensi membaca permulaan baik pada difabel yaitu tunagrahita ringan maupun pada anak yang memiliki kondisi fisik normal.

Terkhusus untuk anak hiperaktif, (Putra 2018) berpendapat bahwa model literasi multisensori/metode VAKT membutuhkan penggunaan metode, media dan meteri yang tepat demi menjamin sampainya pembelajaran dengan baik.

Untuk anak hiperaktif bersosialisasi dan berbicara dengan orang lain tentu akan membantu mengurangi gejala hiperaktifnya. Berbicara dengan orang lain akan mengoptimalkan modalitas pendengaran (auditori). Sedangkan dengan kegiatan menggambar, menulis dan mewarnai gambar anak akan dilatih mengoptimalkan modalitas visual, kinestetik dan taktil. Berikut aspek-aspek sensor dalam model multisensory/VAKT yang dapat dijadikan alternative dalam mengurangi gejala hiperaktif;

Tabel 1. Aspek-aspek sensor dalam metode multisensory/VAKT (Putra 2018)

\begin{tabular}{lllll}
\hline Multisensori/VAKT & Multimetode & Multimedia & Materi \\
\hline $\begin{array}{l}\text { Visual } \\
\text { (Penglihatan) }\end{array}$ & $\begin{array}{l}\text { Melihat, mengamati } \\
\text { objek dan gambar, buku bergambar, Pengembangan kosa } \\
\text { mengidentifikasi nama dengan huruf, kartu huruf, kata dan } \\
\text { objek, membedakan } \\
\text { dua objek atau lebih }\end{array}$ & $\begin{array}{l}\text { huruf, bergambar dengan ekspresif dan reseptif } \\
\text { cerita, buku cerita } \\
\text { bergambar }\end{array}$ \\
& Bercakap-cakap, & CD lagu, CD Pemahaman bahaasa \\
\hline
\end{tabular}




\begin{tabular}{|c|c|c|c|}
\hline (Pendengaran) & $\begin{array}{l}\text { bernyanyi, } \\
\text { mendongeng }\end{array}$ & $\begin{array}{l}\text { dongeng, boneka } \\
\text { tangan }\end{array}$ & $\begin{array}{l}\text { dan huruf, kesadaran } \\
\text { fonologis }\end{array}$ \\
\hline $\begin{array}{l}\text { Kinestetik dan } \\
\text { Taktil }\end{array}$ & $\begin{array}{l}\text { Melipat, menempel, } \\
\text { menggunting, } \\
\text { menuliskan, meraba, } \\
\text { menggambar, mencari } \\
\text { harta karun, bermain } \\
\text { pasir, plastisin atau } \\
\text { puzzle, memasukan } \\
\text { benda ke kotak, } \\
\text { melukis dengan jari, } \\
\text { dan bermain peran }\end{array}$ & $\begin{array}{l}\text { Kertas lipat, kartu } \\
\text { huruf, gunting, } \\
\text { lem,buku gambar, } \\
\text { spidol, } \\
\text { pasir,puzzle,plastisin, } \\
\text { fingerpainting, kotak }\end{array}$ & $\begin{array}{l}\text { Keterampilan } \\
\text { motorik, kreatuvitas, } \\
\text { kemampuan } \\
\text { berkomunikasi dan } \\
\text { interaksi, pengenalan } \\
\text { bentuk }\end{array}$ \\
\hline
\end{tabular}

\section{Pembahasan}

Berdasarkan tabel 1, metode VAKT ini akan membantu guru dalam mengajarkan membaca permulaan pada anak hiperaktif, jika guru mengetahui langkah-langkah pembelajaran dengan mempertimbangkan aspek-aspek sensor penggunaan metode ini; langkah pertama dari aspek visual yaitu, guru mulai membagikan katu huruf lalu mengucapkannya, lalu siswa diminta untuk melihat dan ikut mengucapkannya, langkah kedua dari aspek auditori, guru mengucapkan bunyi guru dan siswa mendengar dan mengikutinya, selanjutnya guru akan bertanya ke siswa bunyi huruf tersebut lalu siswa menyebutkan bunyinya, langkah ketiga dari aspek kinestetik, guru menuliskan huruf yang diajarkan diudara, dan siswa mengikutinya. Dan langkah yang terakhir adalah aspek taktil, guru membagikan kartu huruf lagi dan setelah terbagi rata kesemua siswa, guru meminta siswa untuk meraba kartu huruf dengan mengikuti bentuk huruf yang ada di kartu.

Setelah mengetahui prosedur dalam metode VAKT/Multisensori ini niscaya, jika mengajarkan membaca permulaan pada anak hiperaktif pendidik harus sesuai dengan prosedur pembelajaran metode ini. Selain itu pendidik juga harus bisa membuat pembelajaran seaktraktif mungkin serta inovatif, dan pasti menggunakan media pembelajaran. Penggunaan media pembelajaran menurut Tutupoli dalam Putra, didapati bahwa media pembelajaran kapabel dalam memunculkan stimulan, kegemaran serta ketertarikkan yang baru. Media akan menarik perhatian anak serta dapat meningkatkan daya pemusatan perhatian untuk belajar maupun mempelajari suatu materi. Oleh karena itu, penggunaan media urgent digunakan pada anak hiperaktif yang kerap kali kesulitan memfokuskan konsentrasi.

Pembelajaran juga harus dilakukan secara berkelompok karena menurut Putra, bersosialisasi dan melibatkan semua sensori maka terbukti akan mengurangi efek hiperaktif pada anak ADHD/Hiperaktif ini. Sehingga metode VAKT tidak hanya sebagai solusi dalam kesulitan belajar membaca permulaan pada anak tunagrafia saja, tetapi juga sebagai solusi dalam kesulitan belajar membaca permulaan pada anak hiperaktif.

\section{PENUTUP}

Dari hasil dan pembahasan di atas dapat diambil kesimpulan bahwa, metode VAKT dapat menjadi solusi kesulitan belajar membaca permulaan pada tunagrahita maupun pada siswa normal. Metode VAKT/multisensori dapat menjadi solusi mengatasi kesulitan belajar membaca permulaan pada anak hiperaktif, tetapi guru harus mengikuti langkah-langkah metode VAKT ini dengan baik dan perlu memperhatikan 
penggunaan media pembelajaran dan dilakukan secara berkelompok sebagai upaya untuk mengurangi efek dari hiperaktif pada anak ADHD/hiperaktif.

\section{UCAPAN TERIMAKASIH}

Dengan selesaainya penelitian ini, kami ucapkan terimakasih kepada Prodi PGMI Program Magister UIN Sunan Kalijaga yang telah membimbing dan memberikan dukungan. Ucapan terimakasih juga kami haturkan kepada MI Al-Iman Tambakrejo yang telah memberikan sokongan serta sarana-prasarana sehingga penelitian ini berjalan mulus tanpa halangan apapun dan selesai sesuai dengan yang diharapkan.

\section{DAFTAR PUSTAKA}

Akbar, Sukma Noor. 2017. "Terapi Modifikasi Perilaku untuk Penanganan Hiperaktif Pada Anak Retardasi Mental Ringan.” Jurnal Ecopsy 4(1):41. doi: 10.20527/ecopsy.v4i1.3414.

Arifa, Tutus Rani. 2018. "Hubungan Berpikir Kritis dan Membaca Pemahaman Dengan Kemampuan Menulis Argumentasi." Muallimuna: Jurnal Madrasah Ibtidaiyah 4(1):50. doi: 10.31602/muallimuna.v4i1.1427.

Batubara, Hamdan Husein. 2018. "Pengembangan Media Pembelajaran Matematika berbasis Android untuk Siswa SD/MI." Muallimuna: Jurnal Madrasah Ibtidaiyah 3(1):12. doi: 10.31602/muallimuna.v3i1.952.

Destiani, Lusy. 2016. "Peningkatan Kemampuan Menulis Permulaan menggunakan Metode Vakt (Visual Auditori Kinestetik Taktil) untuk Anak Autis Kelas I di SLB Autisma dian amanah yogyakarta." Widia ortodidaktika 5(11):1101-1109.

Faradila, Arsi. t.t. "Penerapan Metode Vakt (Visual, Auditori, Kinestetik dan Taktil) Untuk Meningkatkan Kemampuan Membaca Permulaan Anak Tunagrahita Ringan SKRIPSI." 53.

Khaliq, Abdul, Barsihanor Barsihanor, dan Tutus Rani Arifa. 2020. "Pengaruh Penggunaan Media Boneka Tangan terhadap Keterampilan Menyimak Siswa Kelas I Di Sdit Robbani Banjarbaru." Muallimuna : Jurnal Madrasah Ibtidaiyah 5(2):42. doi: 10.31602/muallimuna.v5i2.2883.

Nirlianti, Ria. t.t. "Penerapan Metode Vakt (Visual, Auditory, Kinesthetic, Tactile) Untuk Meningkatkan Kemampuan Membaca Permulaan Siswa Kelas 1 di SDN 1 Mareje Timur Lembar Lombok Barat Tahun Pelajaran 2017/2018.” 111.

Nurraga, Adya. 2016. "Pengaruh Metode Vakt terhadap Kemampuan Membaca Permulaan Anak Tunagrahita Ringan Di Slb Purnama Asih.” PhD Thesis, Universitas Pendidikan Indonesia.

Puput, Purnamasari, dan Soendari Tjutju. t.t. "Metode Vakt untuk Pembelajaran Membaca Permulaan Anak Tunagrahita Ringan.” JASSI ANAKKU 19(1):25-31.

Putra, Andi Purnawan. 2018. "Meningkatkan Kreativitas Anak dengan ADHD melalui Literasi." Abdau: Jurnal Pendidikan Madrasah Ibtidaiyah 1(2):354-370.

Putri Pangesti Rahayu, Suwarno. 2016. "Analisis Tentang Anak Hiperaktif dan Upaya Mengatasinya Pada Siswa Kelas Iii Sd Muhammadiyah 5 Surakarta Tahun Ajaran 2015/2016." The Progressive and Fun Education Seminar.

Raudlatul Jannah. 2016. "Pengembangan Buku Ajar Tematik Bernuansa Islami untuk Madrasah Ibtidaiyah/ Sekolah Dasar Islam." Muallimuna: Jurnal Madrasah Ibtidaiyah 2(1):1-16. doi: 10.31602/muallimuna.v3i1.952. 
Roshinah, Fithroh Roshinah, Laila Nursaliha, dan Saiful Amri. 2014. "Pengaruh Terapi Murottal Terhadap Tingkat Hiperaktif-Impulsif Pada Anak Attention Deficit Hyperactive Disorder (Adhd)." Pelita-Jurnal Penelitian Mahasiswa UNY 9(02).

Sutisna, Nia, dan Ayi Rahmawati. 2018. "Pengaruh Metode Vakt terhadap Peningkatan Kemampuan Mengenal Bangun Datar Pada Anak Cerebral Palsy." PEDAGOGIA 16(2):157. doi: 10.17509/pdgia.v16i2.11334.

Tentama, Fatwa. 2009. "Peran Orang Tua dan Guru dalam Menangani Perilaku Hiperaktifitas pada Anak ADHD di SLB Negeri 3 Yogyakarta.” Jurnal KesMas 3(1):51-57. 